\title{
PENANAMAN JIWA KEWIRAUSAHAAN PADA SISWA SEKOLAH DASAR
}

\author{
Rifki Afandi \\ e-mail: wanyiect@yahoo.com
}

\begin{abstract}
The root of the problem in this research is the difficulty of creating a community environment that is entrepreneurial. One way that can be used to overcome that is based entrepreneurship education reform by providing entrepreneurial base as early as possibl. To overcome these problems, this research will develop an integrated learning device immersed oriented type of entrepreneurial spirit in the third grade. This research is the development, aims to develop the entrepreneurial spirit based learning social studies in elementary school, learning tools developed BAS, lesson plans, worksheets, and THB. The procedure is done through a two-stage study, the development of learning tools and testing devices. The device refers to a model developed by Dick and Carey. Device trial study design using one group pretest-posttest design. The subjects were students of class III SD Muhammadiyah Gresik GKB. Data collection techniques are observation, administration of questionnaires, and interviews. All data were analyzed descriptively qualitative and quantitative descriptive. The results showed that: (1) the quality of the IPS based learning entrepreneurship in developed grade III in the review of the validity of the content, format, and language is valid, (2) a low level of difficulty BAS and BAS readability level very high and easy to understand (3) implementation of the IPS -based learning in elementary entrepreneurial spirit developed in terms of adherence to the RPP achieve good feasibility, student activity showed that activitybased entrepreneurial spirit, good student response, student learning outcomes achieved can achieve mastery and constraints on testing time try is crowded during the learning progress of students. IPS devices based learning entrepreneurship in SD in terms of quality, complexity and readability BAS, and implementation can be categorized either.
\end{abstract}

Abstrak: Akar masalah dalam penelitian ini adalah kesulitan menciptakan lingkungan masyarakat yang berjiwa kewirausahaan. Salah satu cara yang dapat digunakan untuk mengatasinya yaitu reformasi pendidikan yang berbasis kewirausahaan dengan memberikan dasar kewirausahaan sedini mungkin. Untuk mengatasi masalah tersebut, pada penelitian ini akan dikembangkan suatu perangkat pembelajaran terpadu tipe immersed yang berorientasi jiwa kewirausahaan di SD kelas III. Penelitian ini merupakan penelitian pengembangan, bertujuan untuk mengembangkan perangkat pembelajaran IPS berbasis jiwa kewirausahaan di sekolah dasar, Perangkat pembelajaran yang dikembangkan adalah BAS, RPP, LKS, dan THB. Prosedur penelitian dilakukan melalui dua tahap, yaitu pengembangan perangkat pembelajaran dan uji coba perangkat. Perangkat yang dikembangkan mengacu pada model Dick and Carey. Uji coba perangkat menggunakan rancangan penelitian one group pretest-posttest design. Subjek penelitian adalah siswa kelas III SD Muhammadiyah GKB Gresik. Teknik pengumpulan data adalah observasi, pemberian angket, dan wawancara. Semua data penelitian dianalisis deskriptif kualitatif dan deskriptif kuantitatif. Hasil penelitian menunjukkan bahwa : (1) Kualitas perangkat pembelajaran IPS berbasis jiwa kewirausahaan di SD kelas III yang dikembangkan ditinjau dari validitas isi, format, dan bahasa dinyatakan valid, (2) Tingkat kesulitan BAS rendah serta tingkat keterbacaan BAS sangat tinggi dan mudah dipahami (3) implementasi perangkat pembelajaran IPS Berbasis jiwa kewirausahaan di SD yang dikembangkan ditinjau dari keterlaksanaan RPP mencapai keterlaksanaan yang baik, aktivitas siswa menunjukkan adanya aktivitas yang berbasis jiwa kewirausahaan, respon siswa baik, hasil belajar yang dicapai siswa dapat mencapai ketuntasan dan hambatan yang pada waktu uji coba adalah siswa ramai saat pembelajaran berlangsung. Perangkat pembelajaran IPS berbasis jiwa kewirausahaan di SD ditinjau dari kualitas, tingkat kesulitan dan keterbacaan BAS, dan implementasinya dapat dikategorikan baik. 
Kata Kunci: Pembelajaran IPS, jiwa kewirausahaan

\section{PENDAHULUAN}

Era globalisasi tidak bisa dihindari, perkembangan teknologi komunikasi seperti internet (international telecomicati- on network) memudahkan manusia memperoleh informasi begitu cepat, era globalisasi bagi orang tertentu (memiliki kompetensi) merupakan peluang terbesar untuk memperoleh kesuksesan, di sisi lain bagi orang tertentu (tidak memiliki kompetensi) globalisasi merupakan sesuatu hal yang menakutkan.

Permasalahan bangsa Indonesia begitu kompleks. Pada saat ini salah satu tantangan terberat bangsa Indonesia bagaimana mempersiapkan generasi mudah agar mampu bersaing dalam era global. Salah satu permasalahn bangsa Indonesia adalah permasalahan pengangguran semakin meningkat, karena lapangan pekerjaan semakin sempit dan perekonomian nasional juga kurang menggairahkan. Hal ini, terbukti masih banyak demonstrasi para buruh menuntut kenaikan UMR (upah minimum regional) dan agar perusahaan tidak melakukan PHK (pemutusan hubungan kerja).

Kemajuan pembangunan telah menghasilkan banyak tenaga terdidik, namun belum sepenuhnya menggembirakan, karena masih diikuti besarnya angka pengangguran (Alma, 2000), menurut Suryamin Kepala Pusat Badan Statistik (BPS) jumlah pengangguran di Indonesia februari tahun 2012 mencapai 7,61 juta orang (Hida, 2012).

Purnomo (2005:23) Indonesia merupakan negara kepulauan terbesar di dunia, yang memiliki lebih dari 250 suku bangsa dan merupakan salah satu negara penduduk terbesar di dunia yaitu kurang lebih 230 juta jiwa. Apabila penduduk tersebut dibina dengan baik dan di tumbuhkan jiwa kewira- usahaan, akan menjadi aset nasional, sebagai sumber daya manusia (SDM) yang handal dan mampu bersaing dipasar global.

Thomas dan Muller (2000) kewirausahaan dapat dipandang sebagai inkubator untuk produk dan pembaharuan pasar, juga dianggap sebagai katalisator pertumbuhan teknologi sebagai contoh, Jepang menjadi negara maju di Asia, karena disponsori aktivitas kewirausahaan. Jepang memiliki 2\% wirausahawan sedang dan $20 \%$ wirausahawan kecil. Jadi seperlima dari penduduk jepang adalah wirausahawan. Di Indonesia karakteristik wirausahawan dalam memulai wirausaha masih bersifat negative felling dalam menanggung resiko kegagalan, dan kurang percaya terhadap kekuatan sendiri.

Dalam rangka mengembangkan dunia usaha, setidaknya Indonesia harus memiliki 3 juta wirausahawan besar dan 30 juta wirausahawan kecil (Alma, 2000:5), oleh karena itu menurut Harper seperti dikutip oleh Thomas dan Muller (2000) pertumbuhan ekonomi suatu negara berkembang seperti Indonesia akan berjalan dengan baik apabila dirangsang adanya aktivitas kewirausahaan. Sumber lainnya dari data statistik menunjukkan bahwa baru $0,18 \%$ penduduk Indonesia yang berprofesi sebagai pengusaha/entrepreneur (sumber Kompas). Padahal idealnya sebuah negara akan maju jika minimal $2 \%$ penduduknya jadi pengusaha, entah pengusaha mikro, kecil, menengah, ataupun pengusaha besar.

Amerika Serikat memiliki $12 \%$ pengusaha dari total penduduknya, Singapura $7 \%$, Cina dan Jepang juga sekitar 10\%. Menurut Gubenur Jawa Timur Soekarwo untuk meningkatkan pertumbuhan ekonomi dan mengurangi pengangguran di Jawa Timur dibutuhkan 2,24\% pengusaha dari jumlah penduduk Jawa Timur, saat ini jumlah pe- 
ngusaha di Jawa Timur masih di bawah 1\% (Metro Tv, 17 januari 2011).

Terdapat beberapa langkah yang dapat ditempuh permasalahan diatas, yang pertama adalah reformasi pendidikan yang berbasiskan kewirausahaan baik formal maupun in formal. Reformasi ini harus menyentuh perubahan dari sang pengajar dan materi pengajaran itu sendiri. Banyak para ahli mengeluh bahwa kewirausahaan diajarkan oleh pengajar tidak berjiwa wirausaha (kompas, 2003). Sehingga kewirausahaan dipandang sebagai pengetahuan belaka.

Kedua adalah memperbanyak serta memperluas pusat pendidikan dan inkubator kewirausahaan. Selama ini kendala biaya dan geografis sering membebankan wirausahawan Indonesia, yang mayoritas adalah UKM, untuk mendapatkan pendidikan yang baik. Indonesia hanya memiliki 48 inkubator kewirausahaan dan hanya berpusat dipulau jawa (ILO, 2003).

Ketiga adalah memberikan dasar pendidikan kewirausahaan sedini mungkin. Di Indonesia jenjang pendidikan dasar masih belum ada mata pelajaran kewirausahaan, Oleh karena itu untuk memberikan pendidikan kewirausahaan pada siswa sekolah dasar diperlukan perangkat pembelajaran kewirausahaan. Hal ini dapat ditempuh dengan pembelajaran IPS yang berorientasi pada jiwa kewirausahaan. Kebutuhan pengembangan jiwa kewirausahaan ternyata belum bisa terjawab di dunia pendidikan tingkat menengah dan tingkat tinggi. Hasil penelitian menunjukkan bahwa sikap mental kewirausahaan siswa sekolah menengah kejuruan di kota Malang relatif masih rendah yaitu hanya 33,4\% (Sriwiyana, 2004).

Penelitian yang dilakukan oleh mahasiswa Free Enterprise dari Pittsburg State University, menunjukkan bahwa pengembangan jiwa kewirausahaan paling efektif jika dimulai pada pendidikan prasekolah
(Journal of Enterpriseship Education, 1997).

Fischer (1997), Freund (1997) dan Erouch (1997) telah melakukan penelitian pengembangan model pembelajaran yang dididesain untuk mengembangkan jiwa kewirausahaan mulai dari tingkat sekolah dasar (SD). Dole (1997) bersama dengan ti- m mahasiswa Universitas Arkansas membantu guru-guru di delta sungai missisippi untuk mengembangkan mengimplementasikan, dan melakukan test program inovasi dalam bentuk perusahaan-perusahaan bisnis dalam rangka pembelajaran di sekolah dasar (SD).

Somantri (2001: 79) mengemukakan bahwa IPS digambarkan sebagai program pendidikan yang memilih bahan pendidikan dari disiplin ilmu-ilmu sosial dan humanitis yang diorganisasikan dan disajikan secara ilmiah dan psikologis untuk tujuan pendidikan. Kedudukan Pendidikan Ilmu Pengetahuan Sosial (PIPS) merupakan salah satu mata pelajaran yang di dalamnya mengkaji seperangkat peristiwa, fakta, konsep, dan generalisasi yang berkaitan dengan isuisu sosial. Pada jenjang pendidikan dasar (SD/MI), mata pelajaran IPS memuat materi geografi, sejarah, sosiologi, dan ekonomi (Permendiknas, 2006). Sejalan dengan hal tersebut pendidikan kewirausahaan dapat dijadikan salah satu alternatif dalam mengatasi permasalahan-permasalahan sosial melalui pembelajaran IPS.

Menurut Pasal 3 Undang-undang Nomor 20 Tahun 2003 Tentang Sistem Pendidikan Nasional, disebutkan bahwa pendidikan nasional berfungsi mengembanngkan kemampuan dan membentuk watak serta peradapan bangsa yang bermartabat dalam rangka mencerdaskan kehidupan bangsa bertujuan untuk berkembangnya potensi peserta didik agar menjadi manusia yang beriman dan bertaqwa kepada Tuhan Yang Maha Esa, berakhlak mulia, sehat, berilmu, cakap, kreatif, mandiri, dan menjadi warga 
negara yang demokratis serta bertanggung jawab. Berdasarkan fungsi dan tujuan pendidikan nasional di atas, pendidikan kewirausahaan dapat dijadikan salah satu wahana mensukseskan tujuan pendidikan nasional. Dan ini didukung instruksi presiden (INPRES) Nomor 4 tahun 1995 tentang Gerakan Nasional Masyarakat dan Membudayakan Kewirausahaan (GNMMK).

Berdasarkan beberapa uraian di atas, menunjukkan bahwa pembelajaran kewirausahaan dapat menjadi salah satu alternatif penanaman jiwa kewirausahaan.

Penelitian ini merupakan penelitian pengembangan, Menurut Sugiono (2011) penelitian pengembangan adalah penelitian yang di gunakan untuk menghasilkan produk tertentu dan menguji efektifitas produk tersebut. Pengembangan dalam penelitian ini adalah perangkat pembelajaran berbasis kewirausahaan. Perangkat pembelajaran yang dikembangkan adalah Buku Ajar Siswa, Rencana Pelaksanaan Pembelajaran (RPP), Lembar Kerja Siswa (LKS), dan Tes Hasil Belajar (THB).

Pengembangan penelitian mengadaptasi pada desain pengembangan perangkat Dick \& Carey, subjek penelitian adalah siswa kelas III SD Muhammadiyah GKB Gresik. Penelitian ini dilakukan dua tahap, tahap pertama pengembangan perangkat pembelajaran IPS berbasis jiwa kewirausahaan dan tahap ke dua adalah uji coba perangkat yang sudah di kembangkan, uji coba perangkat pembelajaran menggunakan design one shot case study, uji coba perangkat dilakukan dua kali yaitu uji coba I dan uji coba II. Teknik pengumpulan data dilaksanakan dengan cara observasi, angket, wawancara, dan dokumentasi. Teknik analisis data dengan menggunakan mixing methods yaitu deskriptif kuantitatif dipadukan dengan deskriptif kualitatif.

Penelitian ini menggunakan model pengembangan perangkat Dick \& Carey, sebagaimana yang dikutip oleh Ibrahim (2-
003: 17-22), selanjutnya diadaptasi oleh peneliti didasarkan pada ketentuan dan kebutuhan dalam pembelajaran IPS berbasis kewirausahaan.

\section{PEMBAHASAN}

Kualitas perangkat pembelajaran diditinjau dari validasi perangkat, yaitu validasi RPP, validasi BAS, validasi LKS, dan validasi THB. Perangkat pembelajaran yang telah dikembangkan kemudian divalidasi oleh 2 orang pakar/ahli. Sebagaimana dikemukakan Reigeluth (dalam Prawiradilaga, 2008:28) yang menyatakan bahwa pengembangan pembelajaran merupakan proses pelaksanaan di lapangan dari apa yang sudah diselesaikan dalam disain yang merupakan kisi-kisi (blueprint) yang masih harus divalidasikan ketepatannya. Penilaian yang dilakukan parkar/ahli sebagai validator meliputi tiga kategori yaitu isi, format, dan bahasa. Berikut analisis deskriftif hasil validasi perangkat pembelajaran yang meliputi hasil validasi RPP, hasil validasi BAS, hasil validasi LKS dan hasil validasi THB.

\section{Analisis Deskripsi Hasil Validasi RPP}

Sebagaimana dijelaskan dalam Permendiknas No. 41 tahun 2007 tentang Standar Proses untuk Satuan Pendidikan Dasar dan Menengah, bahwa setiap guru pada satuan pendidikan berkewajiban menyusun RPP secara lengkap dan sistematis agar pembelajaran berlangsung secara interaktif, inspiratif, menyenangkan, menantang, memotivasi peserta didik untuk berpartisipasi aktif, serta memberikan ruang yang cukup bagi prakarsa kreatifitas, dan kemandirian sesuai dengan bakat, minat, dan perkembangan fisik serta psikologis peserta didik. Hasil penelitian dengan kriteria baik pada setiap kategori menunjukkan bahwa komponen-komponen penyusun RPP telah terpenuhi dengan benar, sehingga dapat disim- 
pulkan bahwa RPP yang dikembangkan sesuai dan layak digunakan sebagai perangkat pembelajaran.

\section{Analisis Deskripsi Hasil BAS}

Berdasarkan analisis hasil penilaian kelayakan BAS oleh validator 1 menunjukkan rata-rata skor penilaian dari tiga kategori (format, isi dan bahasa) sebesar 3,96 dengan kriteria baik. Hasil validator 2 menunjukkan rata-rata skor penilaian dari tiga kategori (format, isi dan bahasa) sebesar 4,00 dengan kriteria baik. Dari skor ratarata kedua validator menjadi 3,96.

Ginting (2008:154) yang menyatakan bahan pembelajaran yang baik harus memenuhi kriteria (1) sesuai dengan topik yang dibahas, (2) memuat intisari atau informasi pendukung untuk memahami materi yang dibahas, (3) disampaikan dalam bentuk kemasan dan bahasa yang singkat, padat, sederhana, sistematis, sehingga mudah dipahami, (4) jika perlu dilengkapi contoh dan ilustrasi yang relevan dan menarik untuk lebih mempermudah isinya, dan (5) memuat gagasan yang bersifat tantangan dan rasa ingin tahu siswa. Hasil penilaian dengan kriteria baik pada setiap kategori menunjukkan bahwa BAS yang dikembangkan memiliki kualitas yang baik. Hal ini didasarkan bahwa komponen ini sudah dikembangkan dengan berbagai tahap dan mengalami revisi berkali-kali misalnya bahasa mudah dipahami, isi sesuai dengan konteks pemahaman siswa.

\section{Analisis Deskripsi Hasil LKS}

Berdasarkan hasil analisis penilaian deskriptif terhadap kelayakan LKS oleh dua orang validator terdapat revisi dan saran yaitu LKS yang dikembangkan didesain dengan menarik agar dapat membangkitkan motivasi siswa sebagaimana ditunjukkan pada tabel dan telah dilakukan perbaikan sesuai saran validator.

Data tentang hasil penilaian deskriptif terhadap kelayakan LKS menunjukkan ratarata skor penilaian validator terhadap tiga komponen yaitu format adalah 4,00 dengan kriteria baik, isi adalah 4,00 dengan kriteria baik, dan bahasa adalah 4,00 dengan kriteria baik. Atas dasar penilaian oleh validator dengan kariteria baik tersebut, memberikan gambaran bahwa LKS yang dikembangkan dalam penelitian ini memiliki kualitas baik, dan telah sesuai dengan standar validitas yang ditentukan oleh Badan Standar Nasional Pendidikan (BSNP, 2006), dengan demikian dapat disimpulkan bahwa LKS tersebut sudah valid dan layak digunakan sebagai perangkat pembelajaran.

LKS yang dikembangkan dalam penelitian ini dirancang secara sistematik agar mudah dipahami oleh siswa, dan petunjuk kerjanya sesuai dengan langkah-langkah pada pembelajaran IPS berbasis jiwa kewirausahaan yaitu mengajarkan keterampilan memahami isi bacaan kepada siswa dengan cara menemukan ide pokok, membuat pertanyaan dan menemukan jawaban, membuat rangkuman, mengklarifikasi kata-kata sulit dipahami dari suatu bacaan, serta siswa diharapkan dapat mempredikasi materi yang akan diajarkan oleh guru pada pertemuan berikutnya. Hal ini sesuai pendapat Sudirman dalam Tuerah (2009) menyatakan LKS merupakan salah satu bahan ajar sebagai sumber belajar yang membawa pesan untuk tujuan pengajaran dan lembar kegiatan yang diupayakan untuk dikuasai oleh siswa.

\section{Analisis Deskriptif THB}

Tes hasil belajar (THB) yang dikembangan berdasarkan indikator pembelajaran yang telah disusun dalam rencana pelaksanaan pembelajran (RPP). Sesuai hasil diskusi dengan guru kelas maka soal-soal da- 
lam tes hasil belajar (THB) ini sebanyak 20 soal pilihan ganda. Sebagaimana dijabarkan dalam Penilaian Hasil Belajar (Ditnaga Depdiknas: 2008) bahwa guru harus memahami prinsip-prinsip penilaian antara lain (1) penilaian hasil belajar hendaknya dirancang dengan jelas kemampuan apa yang harus dinilai, materi atau isi bahan ajar yang diujikan, alat penilaian yang akan digunakan, dan interpretasi hasil penilaian, (2) alat penilaian harus valid. Hasil penilaian untuk komponen validitas isi validator 1 dan valivalidator 2 menunjukkan bahwa tes hasil belajar yang dikembangkan valid, dapat dipahami, dan dapat digunakan tanpa revisi, sehingga bahwa THB yang dikembangkan sesuai dan layak untuk diimplementasikan sebagai perangkat pembelajaran.

\section{Tingkat Kesulitan Dan Keterbacaan Buku Ajar Siswa}

Untuk mengetahui tingkat kesulitan BAS dilakukan dengan cara siswa diminta membaca buku ajar siswa dan menggaris bawahi kalimat yang tidak dimengerti pada buku ajar yang disediakan, pengambilan sampel dilakukan pada 9 siswa, sesuai diskusi dengan guru kelas pada saat uji coba terbatas dengan masukan dari guru yaitu 3 siswa cepat, 3 siswa sedang, dan 3 siswa lambat, dengan asumsi bahwa perangkat pembelajaran ini dapat di gunakan untuk siswa dengan kemampuan apa saja.

Kesulitan dalam memahami buku ajar siswa adalah kata-kata baru yang masih belum pernah dikenal siswa seperti istilah modal utama, wirausaha, dan produksi tidak dipahami oleh siswa, sehingga diperlukan penjelasan khusus. Meski demikian, secara umum buku ajar siswa dapat dipahami dengan baik oleh siswa seperti ditunjukkan oleh persentase tingkat kesulitan buku ajar siswa yang sangat rendah.

William (dalam Tarigan, 1990: 87) menyatakan bahwa satu hal yang harus di- capai dalam membaca yakni pemahaman, sebab kegiatan membaca yang tidak disertai dengan pemahaman terhadap bahan bacaan, sangat erat kaitannya dengan tingkat penguasaan terhadap materi pelajaran. Sejalan dengan hal tersebut, Sagala (2009: 161) menyatakan bahwa bahan pengajaran atau materi ajar yang akan digunakan harus diperiksa terlebih dahulu, supaya guru dapat menentukan apakah bahan tersebut dapat berguna bagi siswa, baik dilihat dari tujuan yang ingin dicapai maupun fungsinya untuk mempelajari bahan berikutnya. Dengan demikian, dalam proses pembelajaran siswa dapat memahami materi dengan baik yang dapat mendukung kelancaran pembelajaran IPS berbasis jiwa kewirausahaan.

\section{Tingkat Keterbacaan BAS}

Keterbacaan BAS yang baik ini akan mendukung upaya peningkatan minat dan penguasaan siswa terhadap materi pelajaran yang disajikan. Klare dalam Suherli (2008) menyatakan bahwa bacaan yang memiliki tingkat keterbacaan yang baik akan mempengaruhi pembacanya dalam meningkatkan minat belajar dan daya ingat, menambahkan kecepatan dan efisiensi membaca, dan memelihara kebiasaan membaca.

\section{Implementasi Uji Coba Perangkat Pembelajaran}

Penerapan perangkat pembelajaran dalam penelitian ini dilakukan masih dalam satu rangkaian tahap pengembangan perangkat pembelajaran, tujuan penerapan adalah untuk mengetahui efektifitas penerapan perangkat pembelajaran dalam menunjang kegiatan pembelajaran. Batasan tentang efektifitas penerapan perangkat pembelajaran adalah ukuran keberhasilan penerapan pembelajaran yang didasarkan pada aspek keterlaksanaan RPP dengan katergori baik, aktivitas siswa selama pembelajaran aktif 
dan menunjukkan pembelajaran berorientasi jiwa kewirausahaan, respon siswa terhadap pembelajaran positif, hasil belajar siswa setelah mengikuti pembelajaran dapat mencapai ketuntasan, sensitivitas butir soal bernilai positif dan rata-rata realibitas instrumen diatas $75 \%$.

Analisis deskriptif tentang efektifitas penerapan perangkat pembelajaran secara operasional dapat dilihat uraian beberapa indikator berikut:

\section{Keterlaksanaan RPP}

Dari hasil analisis data keterlaksanaan RPP seperti ditunjukkan pada tabel tersebut, maka dapat disimpulkan bahwa keterlaksanaan RPP pada penerapan perangkat pembelajaran IPS berbasis dikategorikan sangat baik atau terlaksana. Penilaian yang telah dilakukan oleh dua orang pengamat dapat dipercaya dengan reliabilitas instrument berkategori baik. Hal ini dapat dilihat dari persentase reliabilitas rata-rata $100 \%$. Angka keterlaksanaan tersebut dihasilkan diskusi intensif dengan para validator sebelum penerapan dalam pembelajaran di kelas maupun dengan pengamat dan guru ketika penerapan dikelas.

Pembelajaran IPS berbasis kewirausahaan masih cukup asing bagi para siswa dan guru, namun demikian terdapat dorongan yang kuat untuk dapat melakukan pembelajaran dengan baik. Para siswa meski pada awalnya cukup bingung dalam menyesuaikan diri dengan suasana pembelajaran yang baru, namun setelah pembelajaran berjalan selama beberapa saat, penyesuaian diri dapat dengan mudah dilakukan. Keadaan ini pada akhirnya semakin memudahkan terselenggaranya pembelajaran inkuiri pada berikutnya.

Keterlaksanaan RPP ini juga tidak terlepas dari peranan guru dalam mengelola pembelajaran. Bettencourt (dalam Suparno, 1997) berpendapat bahwa mengajar berarti partisipasi dengan pebelajar dalam membentuk pengetahuan, membuat makna, mencari kejelasan, bersikap kritis, dan mengadakan justifikasi. Sejalan dengan hal tersebut, Djamarah dan Zain (1996: 53) mengemukakan bahwa dalam melaksanakan tugasnya sebagai pengajar seorang guru harus menguasai materi yang diajarkan dan metode yang digunakan dalam pembelajaran. Di samping itu guru juga sudah mampu memanfaatkan komponen kegiatan pembelajaran yang meliputi tujuan, kegiatan belajar mengajar, bahan pengajaran, metode, alat dan bahan secara optimal. Langkahlangkah pembelajaran yang dilakukan guru sudah sesuai dengan sintaks sekenario pembelajaran dalam RPP.

\section{Aktivitas Siswa Selama Pembelajaran}

Aktivitas siswa yang diamati adalah aktivitas sesuai dengan pengembangan aspek jiwa kewirausahaan, aspek jiwa kewirausahaan yang dikembangkan Penelitian terfokus pada karakteristik jiwa kewirausahaan dari sisi personality. Yaitu berkaitan dengan karakter kepribadian yang dimiliki seseorang. Hal ini dilakukan dengan pertimbangan bahwa jiwa karakter-karakter kepribadian yang mengarah pada jiwa kewirausahaan ini diberikan sejak usia dini, maka nantinya akan membentuk perilaku positif siswa tentang sikap berwirausaha. Di samping itu pemilihan beberapa jiwa kewirausahaan dalam penelitian ini (kreatif dan inovatif, kepemimpinan, keyakinan pada kemampuan diri sendiri, kemampuan berkomunikasi, berani mengambil resiko, dan orientasi ke masa depan) sudah didasarkan pada pertimbangan psikologi perkembangan anak Sekolah Dasar.

Berdasarkan analisis data dapat diketahui bahwa keterlaksanaan rencana aktivitas siswa yang dicapai pada uji coba adalah pertemuan 1 rata-rata sebesar $100 \%$ dan pertemuan 2 rata-rata sebesar $100 \%$, artinya 
lembar aktivitas yang dikembangkan dapat diaplikasikan dalam pembelajaran dengan baik dan perangkat tersebut berorientasi jiwa kewirausahaan.

Menurut Mulyasa (2009:187) proses pembelajaran pada hakikatnya untuk mengembangkan aktivitas dan kreatifitas peserta didik melalui berbagai pengalaman belajar. Pembelajaran yang hanya menekankan pada ranah kognitif kegiatan yang demikian hanya menuntun siswa menerima dan menghafal dan hal tersebut jelas mematikan kreatifitas siswa. implementasi KTSP menuntun kemandirian guru untuk menciptakan suasana belajar kondusif yang bisa mengembangkan aktivitas dan kreativitas peserta didik. Dengan pembelajaran IPS berbasis jiwa kewirausahaan tersebut mampu mengembangkan aktivitas dan kreatifitas peserta didik.

\section{Respon Siswa}

Hasil pengisian angket yang dilakukan pada uji coba sebagaimana ditampilkan pada tabel menunjukkan bahwa respon siswa terhadap semua pertanyaan yang diberikan semuanya positif. Hal ini ditunjukkan respon positif yang diberikan oleh semua siswa berada pada tingkatan diatas $80 \%$.

Berdasarkan teori belajar Gagne, belajar merupakan kegiatan yang kompleks. Hasil belajar berupa kapabilitas. Setelah belajar orang memiliki keterampilan, pengetahuan, sikap, dan nilai. Timbulnya kapabilitas tersebut adalah dari stimulus yang berasal dari lingkungan dan proses kognitif yang dilakukan oleh pebelajar. Dengan demikian belajar adalah seperangkat proses kognitif yang mengubah sifat stimulus lingkungan, melewati pengelolaan informasi menjadi kapabilitas baru (Dimyati dan $\mathrm{Mu}-$ djiono, 2006: 10). Adanya kapabilitas tersebut menyebabkan siswa memberikan respon positif.

\section{Tes Hasil Belajar}

Hasil belajar siswa yang dapat mencapai ketuntasan tidak terlepas dari terlaksananya rencana pelaksanaan pembelajaran dengan baik, siswa yang aktif selama belajar mengajar dan respon positif siswa terhadap pembelajaran. Yager (dalam Rohandi, 1998: 121) mengemukakan bahwa hasil belajar bukan semata-mata bergantung apa yang disajikan guru, melainkan dipengaruhi hasil interaksi antara berbagai informasi yang seharusnya diberikan kepada anak dan bagaimana anak mengolah informasi berdasarkan pemahaman yang dimilikinya sebelumnya. Menurut Mulyasa (2009: 208) penilaian hasil belajar pada hakikatnya merupakan suatu kegiatan untuk mengukur perubahan perilaku yang telah terjadi pada peserta didik.

\section{Hambatan-Hambatan yang Muncul}

Beberapa hambatan yang muncul selama proses pembelajaran secara umum tidak dijumpai hambatan yang sangat mengganggu selama pembelajaran, hambatan yang ada masih dapat diatasi oleh peneliti dan guru yang mengajar dalam pembelajaran uji coba.

Dalam belajar yang penting adanya penyesuaian pertama yaitu memperoleh alasan yang tepat untuk memecahkan masalah yang dihadapi. Belajar yang penting bukan mengulangi hal-hal yang harus dipelajari, tetapi mengerti atau memperoleh insight (Teori Gestalt oleh Koffka dan Kohler dalam Slameto, 2003).

Pengalaman yang konkret dan dinamis merupakan alat untuk menyusun pengertian yang bersifat sederhana, sehingga pengalaman itu dapat ditiru untuk diulangi. Siswa memperoleh pengertian umum dengan pasti dan lebih baik serta kuat tanggapannya karena dengan contoh-contoh sedershana. Suatu konteks yang sederhana tetapi 
terlimpah, akan memberikan pekerjaan dan kesmpatan untuk mengadakan eksperimen yang cukup banyak bagi siswa (Slameto, 2003). Hal ini senada dengan kendalakendala yang dihadapi selama proses pembelajaran.

\section{KESIMPULAN}

Berdasarkan uraian dan temuan yang diperolah dalam penelitian ini dapat dikemukakan kesimpulan sebagai berikut: Pengembangan perangkat pembelajaran IPS berbasis jiwa kewirausahaan ditinjau dari isi, format dan bahasa dinyatakan valid. Tingkat kesulitan BAS rendah serta tingkat keterbacaan BAS sangat tinggi dan mudah dipahami.

Hasil implementasi perangkat pembelajaran yang dikembangkan: rencana pelaksanaan pembelajaran (RPP) selama kegiatan pembelajaran mencapai keterlaksanaan yang baik, aktivitas siswa selama kegiatan pembelajaran menunjukkan aktif, respon siswa terhadap diterapkan pembelajaran IPS berorientasi jiwa kewirausahaan dalam pembelajaran menunjukkan respon yang baik.

Hasil belajar siswa selama diterapkan pembelajaran IPS berbasis jiwa dapat mencapai ketuntasan baik. Hambatan yang ditemukan pada pelaksanaan pembelajaran dapat diatasi oleh guru sehingga proses pembelajaran berjalan dengan baik.

Pembelajaran dengan menggunakan perangkat pembelajaran IPS berbasis jiwa kewirausahaan mampu menanamkan jiwa kewirausahaan dengan baik.

\section{DAFTAR PUSTAKA}

Alma, B, Kewirausahan, Bandung: Alfabeta.

Al Muchtar, S. 2004. Pengembangan Berfikir dan Nilai Dalam Pendidikan IPS Bandung: Gelar Pustaka Mandiri.
BSNP. 2006. Panduan Penyusunan Kurikulum Tingkat Satuan Pendidikan Jenjang Pendidikan Dasar dan Menengah. Jakarta. BSNP.

Crouch, H. Jane. 1997. Developing The Entrepreneurial Spirit, Pittsburg State University: Journal of Entrepeneurship Education, Volume 1, Number 1.

Depdiknas RI. 2006. Peraturan Mendiknas Nomor 22 Tahun 2006 Tentang Standar Isi. Jakarta: Depdiknas.

Dick, W. \& Carey, L., 2003 The Systematic Design of Instruction. Glenview, Illinios: Scott, Foresman and Company.

Dimyati dan Mujiono. 2002. Belajar dan pembelajaran. Jakarta: PT Asdi Mahasatya

Djamarah, S.B. \& Zain, A. 1996. Strategi Belajar Mengajar. Jakarta: Rhineka Cipta

Fishcher, K. Arthur. 1997. Developing The Entrepreneurial Spirit among Kindergarten, Journal of Entrepreneurship Education, Volume 1, Number 1, Pittsbrug State.

Fraedrich, P. J. And Guerts, D., 1990, Ethical Awareness for the Classroom : A Framework, Journal of Education for Business, November/December, Volume 66 (2) : 88-93

Freund, M. June. 1997. Developing The Entrepreneurial Spirit Kindergarten through Twelfth Grade Students, Journal of Entrepreneurship Education, Volume 1, Number 1, Puttsbrug State University.

Gintings, P. 2008. Trik dan Taktik Mengajar, Strategi Meningkatkan Pencapaian Pengajaran di Kelas. Jakarta: PT. Indeks.

Hamalik, Oemar. 2004. Proses Belajar Mengajar. Jakarta: Bumi Aksara.

Heriawan. 2011. Jumlah Tenaga Kerja di Indonesia. www.Finace.Detik.com: diakses 20 Agustus 2011. 
Hida, E. Ramdhania. 2012. BPS: Jumlah Pengangguran Indonesia 7,61 Juta, Turun 6\%. http://finance.detik.com/ $\mathrm{read} / 2012 / 05 / 07 / 141833 / 1911053 / 4 / \mathrm{b}$ ps-jumlah-pengangguran-di-indonesia-761-juta-turun-6. diakses 2 maret 2013.

Kardi, S. 2002. Mengembangkan Tes Hasil Belajar. Departemen Pendidikan Nasonal. Surabaya: Universitas Negeri Surabaya

Mulyasa, E. 2009. Implementasi Kurikulunm Tingkat Satuan Pendidikan Kemandirian Guru dan Kepala Sekolah. Jakarta: Bumi Aksara.

Purnomo, H. Bambang .2005. Membangun Semangat Kewirausahaan. Yogyakarta: Laksbang Pressindo.

Rohandi, R. 1998. Memberdayakan Anak Melalui Pendidikan Sains (dalam Sumaji. 1998). Pendidikan Sains yang Humanis. Yogyakarta: Kanisaius.

Sagala, S. 2009. Konsep dan Makna Pembelajaran. Bandung: Alfabeta.

Sapriya, dkk. 2007. Pengembangan Pendidikan Ilmu Pengetahuan Sosial. Bandung: UPI Press.

Slameto, 2003. Belajar dan Faktor-faktor yang Mempengaruhinya. Jakarta: PT Rhineka Cipta.

Suherli. 2008. Keterbacaan Buku Teks Pelajaran. Read-herli. Blogspot.com, diakses pada tanggal 28 Juli 2011.

Suparno, P. 1997. Filsafat Konstruktifisme dalam Pendidikan. Yogyakarta: Kanisius.

Tarigan, H. G. 1990. Membaca Sebagai Suatu Keterampilan Berbahasa Ban-. dung: Aksara. 